O.P. Lazurenko, O.M. Moroz, S.O. Tymchuk, O.O. Miroshnyk, O.A. Savchenko

\title{
OPTIMIZATION OF DESIGN PARAMETERS OF AUTOTRANSFORMERS IN ICE MELTING SCHEME WITH NON-INDUCTIVE CIRCUIT ON 6-10 KV OVERHEAD POWER LINES
}

Purpose. The purpose of the paper is to determine the basic electrical characteristics and to develop a calculation method and algorithm for optimizing the design parameters of autotransformers intended for use in a melting ice scheme with a non-inductive circuit on 6-10 $\mathrm{kV}$ overhead power lines. Methodology. The development of the technical and economic model and the method for calculation of the design parameters of the autotransformer for melting ice is performed on the basis of a systematic approach. Optimization of structural characteristics of autotransformers is carried out using a combined algorithm based on the spatial grid method, adapted to the case of a mixed space of discrete and continuous independent variables, and the specifics of the technical and economic model of the autotransformer. The proposed combined optimization algorithm is implemented in the Delphi environment. Results. Based on the required specific melting power, the main electrical characteristics of autotransformers intended for use in the meltingicr scheme with a non-inductive circuit on 6-10 kV overhead lines, which were the basis for optimizing their design parameters, have been calculated. The technical and economical model of autotransformer for melting ice, which is defined by nine independent variables and describes its cost and technical parameters, is developed. On the basis of the obtained electrical characteristics, optimization of the design parameters of a series of autotransformers is carried out, which includes three standard sizes, differing in maximum length of the transmission line. Originality. A method of calculation of structural parameters of autotransformers for ice melting is proposed, the peculiarity of which is the use of the criterion of the minimum of the cost of the active part and taking into account the conditioned by the circuit of connection of the autotransformers the technical restrictions of errors on the value and angle of secondary current, which are important from the point of view of ensuring the permissible deviation of the specific power of melting ice. Practical value. Optimal correlations of geometrical sizes and electromagnetic loads of autotransformers for ice melting, their cost indicators, as well as the main design characteristics of the magnetic circuit and windings are established. Results of design calculation of autotransformers are sufficient for introduction of their serial production in industrial conditions. References 11, tables 2, figures 4.

Key words:overhead power line, melting of ice, autotransformer for melting of ice, technical and economic model, optimization of design parameters.

Мета. Метою статті є визначення електричних характеристик та розроблення методу розрахунку $і$ алгоритму оптимізації конструктивних параметрів автотрансформаторів, призначених для використання в схемі плавлення ожеледі з безіндуктивним контуром на повітряних лініях електропередач 6-10 кВ. Методологія. Розроблення технікоекономічної моделі та методу розрахунку конструктивних параметрів автотрансформатора плавлення ожеледі виконано на засадах системного підходу. Оптимізація конструкції автотрансформаторів плавлення ожселеді проведена з використанням комбінованого алгоритму на основі методу просторової сітки. Результати. Одержано електричні характеристики та оптимізовано конструктивні параметри серії автотрансформаторів, призначених для використання в схемі плавлення ожеледі з безіндуктивним контуром на повітряних лініях електропередач 6-10 кВ. Наукова новизна. Запропоновано метод розрахунку конструктивних параметрів автотрансформаторів плавлення ожеледі, особливістю якого є використання критерію мінімуму вартості активної частини та врахування зумовлених схемою вмикання автотрансформаторів технічних обмежень похибок за величиною та кутом вторинного струму. Практичне значення. Результати конструктивного розрахунку автотрансформаторів плавлення ожеледі с достатніми для впровадження їх серійного виробнццтва в промислових умовах. Бібл. 11, табл. 2 , рис. 4.

Ключові слова: повітряна лінія електропередач, плавлення ожеледі, автотрансформатор плавлення ожеледі, технікоекономічна модель, оптимізація конструктивних параметрів.

Цель. Целью статьи является определение электрических характеристик и разработка метода расчета и алгоритма оптимизации конструктивных параметров автотрансформаторов, предназначенных для использования в схеме плавки гололеда с безиндуктивным контуром на воздуиных линиях электропередачи 6-10 кВ. Методология. Разработка технико-экономической модели и метода расчета конструктивных параметров автотрансформатора плавки гололеда выполнена на основе системного подхода. Оптимизация конструкции автотрансформаторов плавки гололеда проведена с использованием комбинированного алгоритма на основе метода пространственной сетки. Результаты. Получены электрические характеристики и оптимизированы конструктивные параметры серии автотрансформаторов, предназначенных для использования в схеме плавки гололеда с безиндуктивным контуром на воздушных линиях электропередачи 6-10 кВ. Научная новизна. Предложен метод расчета конструктивных параметров автотрансформаторов плавки гололеда, особенностью которого является использование критерия минимума стоимости активной части и учет обусловленных схемой включения автотрансформаторов технических ограничений погрешностей по величине и углу вторичного тока. Практическое значение. Результаты конструктивного расчета автотрансформаторов плавки гололеда достаточны для внедрения их серийного производства в промышленных условиях. Библ. 11, табл. 2, рис. 4.

Ключевые слова: воздушная линия электропередачи, плавка гололеда, автотрансформатор плавки гололеда, техникоэкономическая модель, оптимизация конструктивных параметров.

Introduction. At present, the most effective way to protect 6-10 $\mathrm{kV}$ overhead transmission lines (OTL), which are widely used in some countries, from the effect of the ice is to melt it [1]. The technology of melting ice is to use a certain melting scheme, which, based on the law of Joule-Lenz, allows to achieve the allocation of thermal 
energy in the unit of the length of the OTL wire, sufficient for melting of deposits within a reasonable time, usually about 1 hour. In order to determine the appropriate amount of thermal energy, in this work the term «specific power of melting ice» is used.

In melting schemes of ice, electrical power melting installations of ice-and-frost deposits (IFDs) are often used, which harmonize the parameters of the power system with the parameters of the lines [2]. An example of such an installation is the autotransformer for melting ice (AMI), which is activated by the melting scheme proposed in [3]. As it is known, the use of autotransformers compared with transformers, due to the electrical connection between the windings, can significantly reduce the power of the electric apparatus. In addition, the feature of the proposed melting scheme is the use of a non-inductive circuit, which reduces the reactive component of the load of the autotransformer to almost zero.

To date, autotransformers, suitable for use in the proposed melting scheme of ice with a non-inductive circuit, are absent. Therefore, there is the task of determining the electrical characteristics of such autotransformers as well as developing a calculation method and algorithm for optimizing their design parameters.

The analysis of existing methods for the calculation of power transformers and autotransformers of industrial series [4-6] showed that they are based on the use of the criterion of reduced costs, which allows to establish the optimal ratio between capital and current costs to the transformer. This approach is not appropriate for autotransformers for melting ice, as they have a small total annual operating time (up to 50-100 h). Consideration in the method of calculating the AMI of current costs will lead to unnecessary complication of its technical and economic model and increase the optimization time of the algorithm. In addition, the existing calculation methods do not take into account determined by the AMI connection circuit the limiting of the angle between the primary and secondary current (angular error limitation) and the relative difference between the primary and the secondary current (current error limit), which are important for the AMI from the point the view of providing the required specific power of melting ice.

The preliminary analysis showed that the dependencies of the parameters of the AMI on the discrete and continuous independent variables is nonlinear, therefore the task of optimizing the design of such an autotransformer is the problem of nonlinear programming. There is a fairly large number of algorithms for solving these problems [7-10]. However, the general methods of solving the problems of nonlinear programming in the mixed space of discrete and continuous variables have not been developed to date. A characteristic drawback of existing methods is that they are not universal. The use of certain artificial techniques allows to reduce the task to any particular type. One of such technique is the transformation of independent variables to one type, such as continuous [10]. But such a technique can give significant errors in the inverse transformation of variables. Transformation of variables to a discrete form is more acceptable, since continuous variables can be discretized with a small step and obtain a solution with a given accuracy, but with high computation costs. However, in the case of the multi-extremity of the objective function and the presence of nonlinear constraints on the permissible domain of solutions, practically all methods of discrete programming are reduced to a continuous enumeration of discrete variables. In [11] an approach to the solution of the problem of nonlinear programming for the case of discrete and continuous variables in the general formulation is proposed. The advantage of this approach is to take into account the specifics of a particular system and its mathematical model, in connection with which it was adopted as the basis for developing a combined algorithm for optimizing the design parameters of autotransformers for melting ice.

The goal of investigations is to determine the electrical characteristics and to develop a calculation method and algorithm for optimizing the design parameters of autotransformers intended for use in a melting scheme of ice with a non-inductive circuit on 6$10 \mathrm{kV}$ overhead power lines.

Calculation of electrical parameters of autotransformers for melting ice. To optimize the design parameters of AMI, it is necessary to calculate their desired electrical characteristics. In [3] an analysis of electrical processes in the melting scheme of ice on the basis of autotransformer with a non-inductive secondary circuit was carried out. It is shown that the proposed scheme allows in melting ice mode to increase the equivalent active resistance of the OTL in number of times

$$
k_{R}=\frac{\left(1+k_{I}\right)^{2}(1-a)+a}{a(1-a) k_{I}^{2}},
$$

where $k_{I}$ is the coefficient of transformation of the AMI by current; $a$ is the coefficient of ratio of active resistance of the external and internal parts of the wire

$$
a=\frac{R}{R_{e}},
$$

where $R, R_{e}$ are the active resistances according to the entire wire and its outer part.

Inductive resistance of the line at the same time practically does not change.

In the AMI series, there were three standard sizes that differ in maximum length of the OTL. Each AMI is intended for the melting of deposits on the OTL with a length from a certain value of $l_{\min }$ to a value of $l_{\max }$. In order to provide the required specific melting power on the OTL with any length within the limits of $l_{\min } \div l_{\max }$, adjustment of the coefficient $k_{R}$ is foreseen. It will also allow to quickly regulate the amount of thermal energy emitted in the wires of the OTL when weather conditions change, to affect the melting time of IFDs.

As the estimated calculations have shown, in order to obtain the required values of the specific melting power, the equivalent active resistance of the OTL should be much larger than the equivalent inductive resistance, so the latter can be neglected. Then the value of the 
coefficient $k_{R}$ to be provided by the AMI can be determined based on the required value of the specific melting ice power $P_{0}=56 \mathrm{~kW} / \mathrm{km}$ [1] based on the expression

$$
k_{R} \approx \frac{U^{2}}{3 P_{0} R_{0} l^{2}},
$$

where $U$ is the nominal voltage of the line, $\mathrm{kV} ; R_{0}$ is the specific active resistance of the wire, $\Omega / \mathrm{km} ; l$ is the OTL length, km.

Then, based on the expressions obtained in [3], the basic electrical parameters of the AMI were calculated. The calculation results are shown in Table 1. Nominal currents and voltages of windings of the AMI were taken equal to the maximum of values possible during the operation of each autotransformer. In addition, Table 1 shows the allowable values of errors in the values of the secondary current and its phase relative to the primary current. The limitation of this error is due to the switching circuit of the autotransformers [3] and is necessary in terms of providing a tolerable deviation of the specific melting power of ice, which influences on the time of melting of deposits and, consequently, the success of this process. For those specified in Table 1 limit values of errors, the possible deviation of power losses in the wire is $\pm 10 \%$.

Technical and economic model of autotransformer. To calculate the AMI, the basics of the methods used to calculate power transformers and autotransformers are used, with some differences. So, since the cost of operating APO, as mentioned above, can be neglected, then as an indicator of their optimization it is proposed to use a relatively simple criterion for the minimum cost of the active part $C \rightarrow \min$.

Table 1

Results of calculation of the main electrical characteristics of autotransformers for melting ice which are the basis for optimizing their design parameters

\begin{tabular}{|c|c|c|c|c|c|c|c|c|c|}
\hline \multirow{3}{*}{ 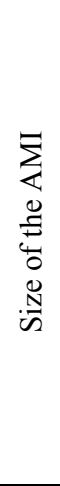 } & \multicolumn{9}{|c|}{ AMI parameters } \\
\hline & \multirow{2}{*}{ 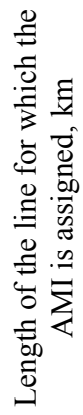 } & \multirow{2}{*}{ 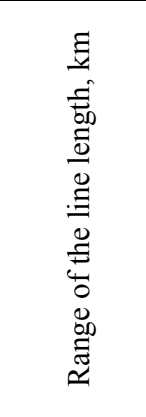 } & \multirow{2}{*}{ 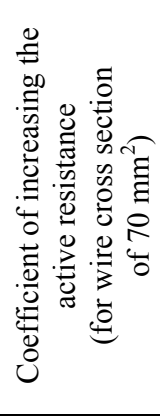 } & \multirow{2}{*}{ 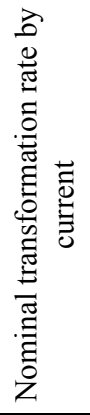 } & \multirow[b]{2}{*}{ 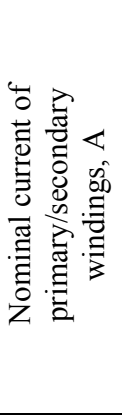 } & \multirow{2}{*}{ 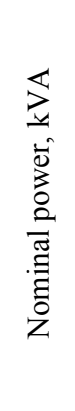 } & \multirow{2}{*}{ 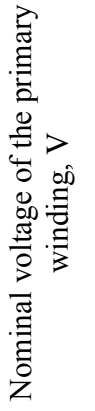 } & \multicolumn{2}{|c|}{ Permissible errors } \\
\hline & & & & & & & & 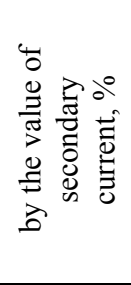 & 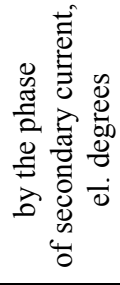 \\
\hline $\begin{array}{l}- \\
\dot{0} \\
\dot{\tilde{N}} \\
\dot{\tilde{N}}\end{array}$ & $4 \div 10$ & $\begin{array}{c}4 \div 4.7 \\
4.7 \div 5.4 \\
5.4 \div 6.3 \\
6.3 \div 7.4 \\
7.4 \div 8.6 \\
8.6 \div 10\end{array}$ & $\begin{array}{l}75.6 \\
55.9 \\
41.6 \\
30.2 \\
22.4 \\
16.5\end{array}$ & $\begin{array}{l}0.28 \\
0.34 \\
0.41 \\
0.51 \\
0.63 \\
0.79\end{array}$ & $110 / 182$ & 2000 & 6000 & -5.4 & \pm 10 \\
\hline 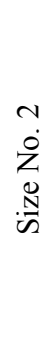 & $4 \div 16$ & $\begin{array}{c}4 \div 4.7 \\
4.7 \div 5.4 \\
5.4 \div 6.3 \\
6.3 \div 7.4 \\
7.4 \div 8.6 \\
8.6 \div 10 \\
10 \div 11.7 \\
11.7 \div 13.7 \\
13.7 \div 16\end{array}$ & $\begin{array}{c}75.6 \\
55.9 \\
41.6 \\
30.2 \\
22.4 \\
16.5 \\
12.0 \\
8.8 \\
6.6\end{array}$ & $\begin{array}{l}0.28 \\
0.34 \\
0.41 \\
0.51 \\
0.63 \\
0.79 \\
1.04 \\
1.40 \\
1.99\end{array}$ & $174 / 182$ & 3200 & 6000 & -5.4 & \pm 10 \\
\hline $\begin{array}{l}n \\
\dot{z} \\
\dot{\tilde{N}} \\
\dot{\tilde{n}}\end{array}$ & $4 \div 25$ & $\begin{array}{c}4 \div 4.7 \\
4.7 \div 5.4 \\
5.4 \div 6.3 \\
6.3 \div 7.4 \\
7.4 \div 8.6 \\
8.6 \div 10 \\
10 \div 11.7 \\
11.7 \div 13.7 \\
13.7 \div 16 \\
16 \div 18.5 \\
18.5 \div 21.5 \\
21.5 \div 25\end{array}$ & $\begin{array}{l}75.6 \\
55.9 \\
41.6 \\
30.2 \\
22.4 \\
16.5 \\
12.0 \\
8.8 \\
6.6 \\
4.8 \\
4.1 \\
3.5\end{array}$ & $\begin{array}{l}0.28 \\
0.34 \\
0.41 \\
0.51 \\
0.63 \\
0.79 \\
1.04 \\
1.40 \\
1.99 \\
3.23 \\
4.67 \\
7.83\end{array}$ & $207 / 182$ & 3200 & 6000 & -5.4 & \pm 10 \\
\hline
\end{tabular}


As noted above, the APO must be provided with an appropriate level of error - by angle and by current

$$
\begin{aligned}
& f_{I} \leq f_{I a}, \\
& \delta_{I} \leq \delta_{I a} .
\end{aligned}
$$

AMI must also be characterized by certain values of the overheating temperature of the windings (primary $\Delta t_{1}$ and secondary $\Delta t_{2}$ ) above the ambient air, which should not be greater than the permissible value for the accepted class of insulation $F$ of the AMI $\Delta t_{a}=140^{\circ} \mathrm{C}$ (taking into account the greatest possible temperature of air during melting ice time $t_{\text {air }}=0{ }^{\circ} \mathrm{C}$ )

$$
\begin{aligned}
& \Delta t_{1} \leq \Delta t_{a}, \\
& \Delta t_{2} \leq \Delta t_{a} .
\end{aligned}
$$

The check for heating the windings during a short circuit was carried out after a detailed calculation of the AMI.

Thus, the task of designing an optimal AMI is to minimize the target function taking into account the given constraints. The technical and economic model of the optimal design of the AMI has the form of the system:

$$
\left\{\begin{array}{l}
C \rightarrow \min \\
f_{I} \leq f_{I a} \\
\delta_{I} \leq \delta_{I a} \\
\Delta t_{1} \leq \Delta t_{a} \\
\Delta t_{2} \leq \Delta t_{a}
\end{array}\right.
$$

AMIs are intended to be performed as three-phase, cast-insulated and with spatial non-breaking magnetic system, which allows for the equalization of the magnetization currents, and hence of the AMI errors, in all three phases, which in turn eliminates the difference in power losses in the melting mode in the wires of various phases [6]. To manufacture the core of the AMI, coldrolled anisotropic steel grade 3405, which is characterized by acceptable magnetic properties at a moderate price, is accepted. The insulation distances of the AMI were based on existing experience in designing transformers and operating standards.

The analysis showed that independent variables, which can describe the design of the AMI, include: $d-$ the diameter of the rod of the autotransformer; $b_{1}, b_{2}, h_{1}$, $h_{2}$ - the dimensions of the wiring of the primary and secondary windings; $n_{1}, n_{2}$ - the number of parallel wires in windings; $N_{l 1}$ - the number of layers of the primary winding; $B$ - the magnetic flux density in the rods of the magnetic system. For the three-phase AMI, dependencies for the target function, as well as the main characteristics, including those that are subject to limitation, on independent variables, are obtained. With the exception of minor differences, they correspond to well-known expressions, which are in the specialized literature on the design and calculation of power transformers, in particular [4-6]. Due to the considerable cumbersome nature of these dependencies and their obviousness, they are not given in this paper.

Optimization of design parameters of autotransformers for melting ice. The initial data for optimization of the design parameters of AMI are their electrical characteristics, shown in Table 1, as well as the parameters of the selected electrical materials.

The analysis of independent variables shows that among the variables that are discretely variable, two groups can be distinguished. The first one is the variables that can take values from the standard-size series $\left(d, h_{1}\right.$, $\left.h_{2}, b_{1}, b_{2}\right)$, the second one is integer variables $\left(N_{l 1}, n_{1}, n_{2}\right)$. The third group is a continuous variable, $B$. Thus, there are three groups of variables in the problem, for variation of which one can use schemes of different methods.

The approach was based on the spatial grid method proposed in [11]. This approach does not impose any restrictions on the type of variables, nor on the efficiency criterion. The enlarged structure of the combined algorithm represents three nested to each other stages (Fig. 1).

\begin{tabular}{|l|} 
Variation of $d, h_{1}, h_{2}, b_{1}, b_{2}$ \\
\begin{tabular}{l} 
Variation of $N_{l 1}, n_{1}, n_{2}$ \\
\hline $\begin{array}{l}\text { Variation of } B, \\
\text { model calculation and } \\
\text { verification of restrictions }\end{array}$ \\
\hline
\end{tabular}
\end{tabular}

Fig. 1. Structure of the combined algorithm for optimization of the AMI

The first (external) stage of the algorithm implements the change of those independent variables that take values from the standard-size series, that is, the transformer structure for the internal stages is fixed. At this stage, it makes sense to replace the variables. The scope of the values of each variable is limited to the standard-size series in the form

$$
\left\{\begin{array}{l}
d=\left\{d_{i}\right\}, i=1, \ldots, n_{d} ; \\
h_{1}=\left\{h_{1 j}\right\}, j=1, \ldots, n_{h} ; \\
h_{2}=\left\{h_{2}\right\}, p=1, \ldots, n_{h} \\
b_{1}=\left\{b_{1 k}\right\}, k=1, \ldots, n_{b} ; \\
b_{2}=\left\{b_{1 m}\right\}, m=1, \ldots, n_{b} .
\end{array}\right.
$$

Each element of a standard-size series corresponds to its serial number (index). Taking into account the unequivocal correspondence of the index to the element of a standard-size series, it is possible to accept their indexes as independent variables of optimization. The optimization task at this stage can be solved in the space of integer variables $i, j, p, k, m$.

The second (middle) stage implements the change of integer independent variables.

At the third (internal) stage, the variation of a continuous variable is performed, since, for fixed design parameters, the target function is continuous. In the internal cycle, the calculation of the target function of the system and verification of restrictions on the permissible decision area are performed.

The structure of the stages in which for each combination of the values of independent variables of the external stage the optimal for these combinations solution of internal stages is found, leads to the implementation of 
the Bellman principle of optimality at the level of the structure of the algorithm.

To determine the possibility of application at different stages of the optimization algorithm of methods other than the grid method, a study was carried out on the dependence of the target function on independent variables. Analyzing the nature of the dependence of the target function on the variable $B$ (Fig. 2,a), it can be noted that in this case the function is unimodal. To find the minimum of the target function in the third stage of the combined algorithm, one can use the scheme of the unidirectional search method, and the principle of minimax is implemented for moving from the maximum value of $B$ to the minimum, since the minimum of the target function is near the maximum value of $B$. The maximum value of the magnetic flux density was

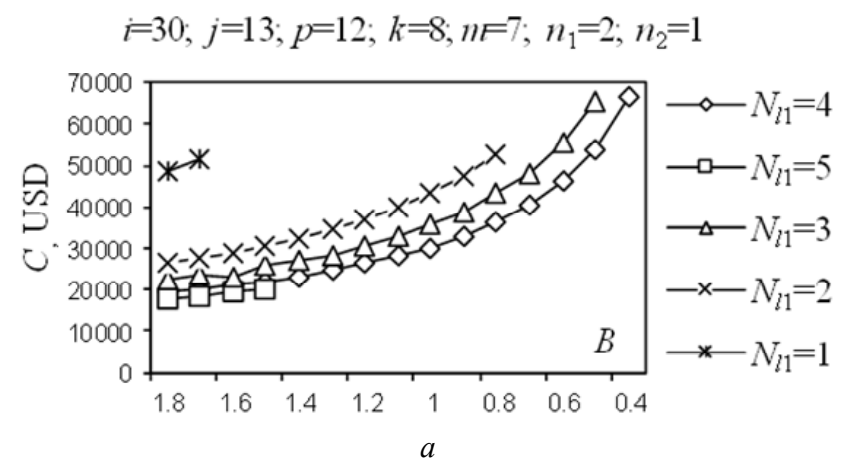

$\dot{I}=30 ; j=13 ; p=12 ; k=10 ; n=8 ; B=1,80$

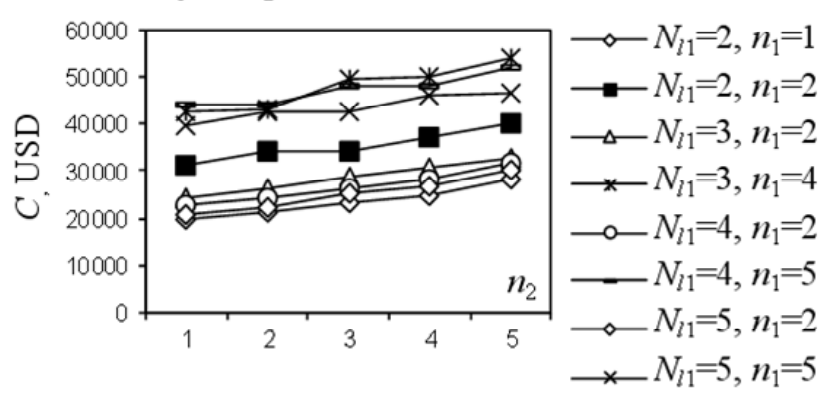

$c$

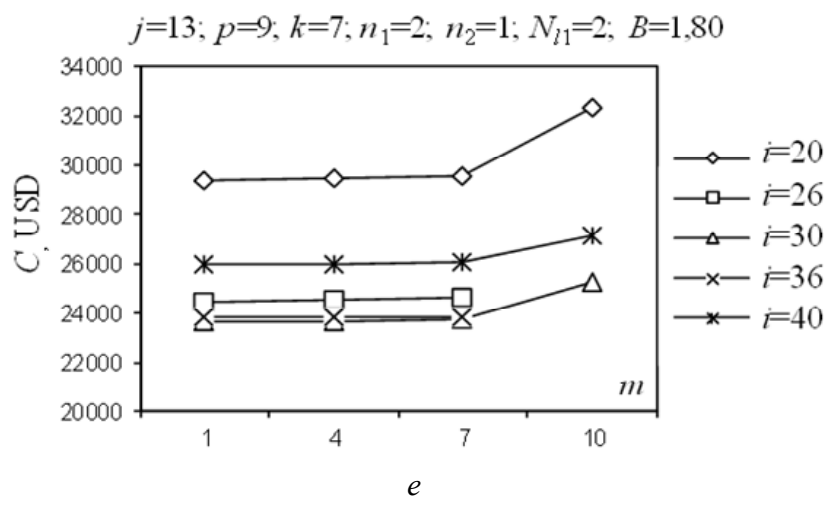

assumed to be equal to $B=1.8 \mathrm{~T}$, since larger values for the accepted steel grade lead to a significant increase in the magnetic field strength, which, in turn, causes an increase in the magnetization current and, as a consequence, the errors of the autotransformer. Greater values of the magnetic flux density also cause a sharp increase in specific losses in steel and its intense heating. To take into account the restrictions of the functional type, imposed on the area of values of the target function, it is rationally to use the penalty function. In this case, it can be quite simple, for example, a constant whose value is clearly greater than the real values of the target function. Taking into account the apparent simplicity, the block diagram of the third stage of the combined algorithm of optimization is not given.
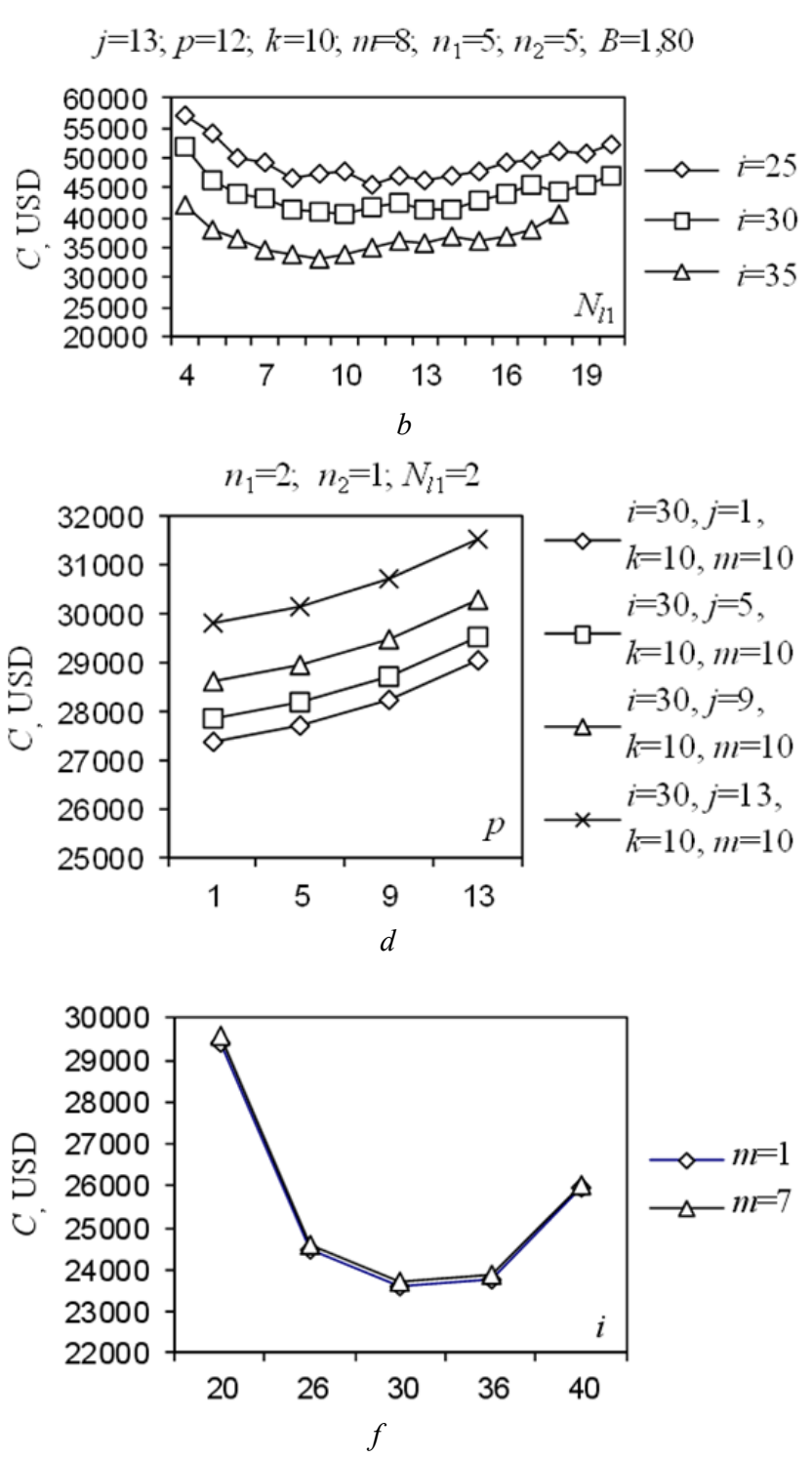

Fig. 2. Preliminary investigations of the target function $C$ (USD)

Analysis of the nature of the dependence of the target function on the variables $N_{l 1}, n_{1}, n_{2}$ (Fig. 2,b,c) shows that in this case the target function is not unimodal. Therefore, at the second stage of the combined algorithm of optimization, one should use the scheme of any method for finding the global optimum. The range of variation of variables at this stage is relatively small. Therefore, the advantage was given to the method of scanning (the variant of the method of full overview of the combinations of values of variables). 
Consideration of functional type restrictions occurs automatically, since for each combination of values of variables $N_{l 1}, n_{1}, n_{2}$ the task of the third stage of optimization is solved, where restrictions have already been taken into account. The algorithm of the scanning method is well known and its block diagram is also not given.

A bit more interest is the definition of the optimization method for the first stage of the combined algorithm. The scope of the change of the independent variables is quite large (for example, $i=1, \ldots, 56$ ), which makes the scanning method ineffective. At the same time, analysis of the nature of the dependence of the target function on independent variables at this stage (Fig. 2,d,e,f) shows that this function is quasi-convex. This fact gives the right to depart from the scheme of the method of full overview of the combinations of values of variables. It is proposed to apply a scheme of spatial grid method with a variable step, adapting it for the case of integer variables (the grid step can not be small).

In the general case, the convergence of the spatial grid method depends on the choice of the initial step of the grid and the law by which this step varies with the narrowing of the search optimum. Calculation investigations of the convergence of the developed variant of the algorithm of the spatial grid method (Fig. 3, 4) showed that the convergence practically does not depend on the value of the initial step of the grid, but the rate of convergence essentially depends on. The minimum search time for the optimum corresponds to the value of the initial step of the grid, in which the number of nodes in the grid will be equal to one of the numbers of the Fibonacci series, namely, the number of nodes in the variable $i-8$, by $j, p, k, m-5$ the calculation time is about 7 minutes. Relative to the law of reducing the step of a grid, then in this case the most studied method of dichotomy is applied.

The proposed combined optimization algorithm was implemented in the Delphi environment. Results of optimization of design parameters of AMI are given in Table 2.

As can be seen from the results of the calculation, the permissible range of solutions for each AMI is primarily due to the overheating temperature of the windings, which in some cases almost corresponds to the permissible. The relatively high value of the permissible overheating temperature $\Delta t_{a}=140{ }^{\circ} \mathrm{C}$, which is associated with the features of the AMI operation (calculation air temperature $t_{\text {air }}=0{ }^{\circ} \mathrm{C}$ ), as well as the external placement of the secondary winding, resulted in rather high values of the density of the current in it. The magnetic flux density in the core of the AMI is close to the maximum. For the standard size of the autotransformer No. 3, the magnetic flux density was slightly lower, which is explained by the activity of the limit on the current error.
Results of optimization of design parameters of autotransformers for melting ice

\begin{tabular}{|c|c|c|c|}
\hline \multirow[t]{2}{*}{ AMI parameters } & \multicolumn{3}{|c|}{$\begin{array}{c}\text { Parameter value } \\
\text { for the standard-sized } \\
\text { AMI }\end{array}$} \\
\hline & No. 1 & No. 2 & No. 3 \\
\hline \multicolumn{4}{|l|}{ Magnetic system: } \\
\hline Rod diameter, mm & 380 & 450 & 560 \\
\hline Rod length, mm & 1464 & 1604 & 1998 \\
\hline Distance between axes of the rods, $\mathrm{mm}$ & 694 & 793 & 927 \\
\hline Total steel mass, $\mathrm{kg}$ & 5082 & 7931 & 14952 \\
\hline Magnetic flux density in steel, $\mathrm{T}$ & 1.80 & 1.80 & 1.78 \\
\hline
\end{tabular}

Windings:

\begin{tabular}{|c|c|c|c|}
\hline Number of layers of primary winding & 3 & 4 & 1 \\
\hline Number of layers of secondary winding & 1 & 2 & 6 \\
\hline Number of wires of primary winding & 2 & 4 & 4 \\
\hline Number of wires of secondary winding & 2 & 1 & 3 \\
\hline Radial wire size of the winding I, mm & 5.60 & 5.60 & 4.50 \\
\hline Axial wire size of the winding $\mathrm{I}, \mathrm{mm}$ & 11.20 & 11.20 & 6.30 \\
\hline Radial wire size of the winding II, mm & 2.00 & 3.15 & 5.60 \\
\hline Axial wire size of the winding II, mm & 4.00 & 11.20 & 6.30 \\
\hline Number of turns of the primary winding & 180 & 130 & 71 \\
\hline $\begin{array}{l}\text { Maximum number of turns of the } \\
\text { secondary winding }\end{array}$ & 142 & 260 & 555 \\
\hline $\begin{array}{l}\text { Overheating temperature of the primary } \\
\text { winding, }{ }^{\circ} \mathrm{C}\end{array}$ & 138 & 133 & 112 \\
\hline $\begin{array}{l}\text { Overheating temperature of the } \\
\text { secondary winding, }{ }^{\circ} \mathrm{C}\end{array}$ & 140 & 134 & 139 \\
\hline $\begin{array}{l}\text { Current density in the primary winding, } \\
\mathrm{A} / \mathrm{mm}^{2}\end{array}$ & 0.88 & 0.69 & 1.83 \\
\hline $\begin{array}{l}\text { Current density in the secondary } \\
\text { winding, } \mathrm{A} / \mathrm{mm}^{2}\end{array}$ & 11.27 & 5.14 & 1.70 \\
\hline
\end{tabular}

Nominal electrical parameters:

\begin{tabular}{|l|c|c|c|}
\hline Primary current, A & 110 & 174 & 207 \\
\hline Secondary current, A & 182 & 182 & 182 \\
\hline $\begin{array}{l}\text { Error in the value of secondary current, } \\
\%\end{array}$ & -1.0 & $-1,5$ & -3.3 \\
\hline $\begin{array}{l}\text { Error in the angle of secondary current, } \\
\text { electric degrees }\end{array}$ & 0.9 & 1,3 & 2.8 \\
\hline
\end{tabular}

General AMI parameters:

\begin{tabular}{|l|l|l|l|}
\hline Autotransformer mass, kg & 7915 & 12812 & 24980 \\
\hline Cost of autotransformer, USD & 18159 & 29328 & 57319 \\
\hline
\end{tabular}




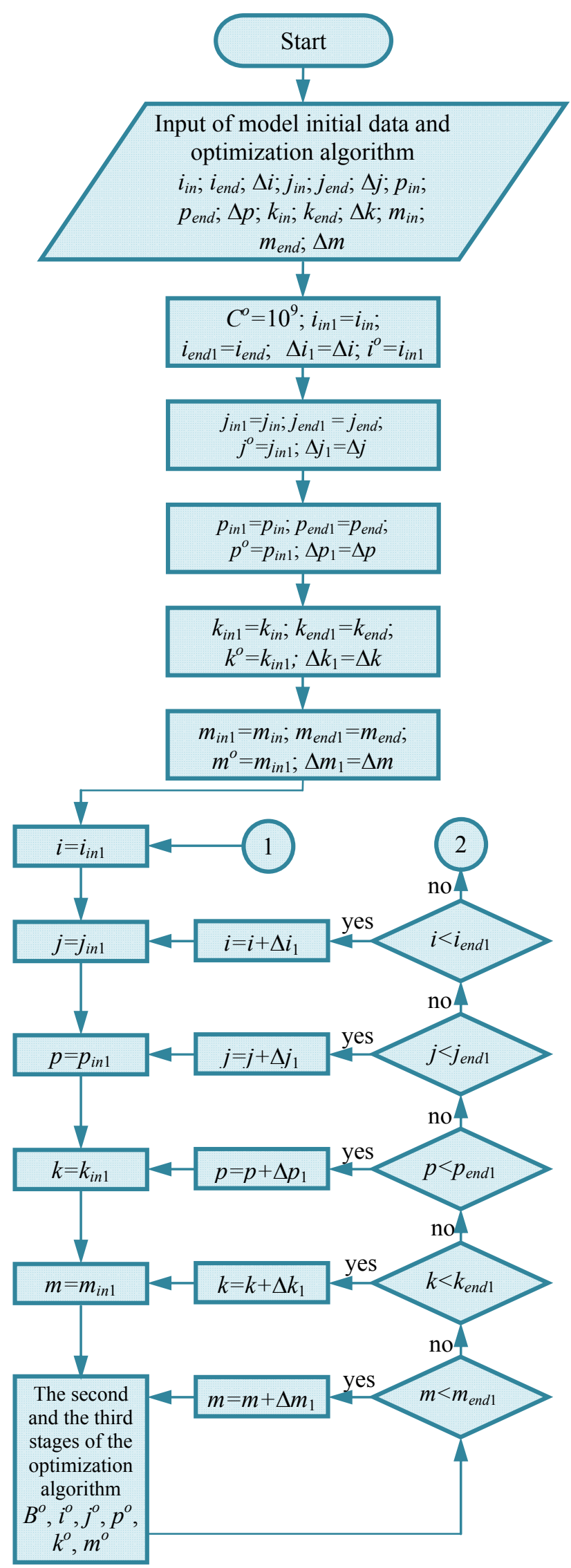

Fig. 3. Block diagram of the first stage of the combined algorithm

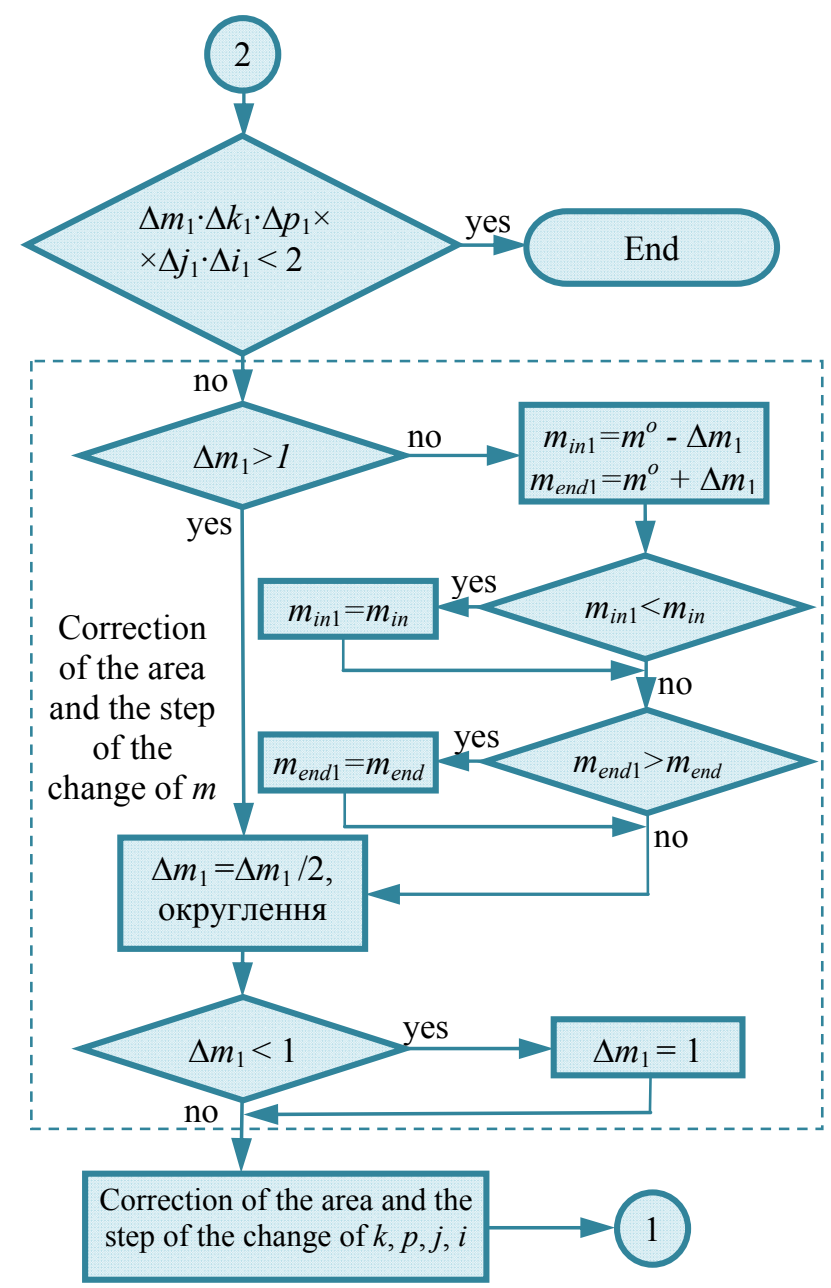

Fig. 4. Block diagram of the first stage of the combined algorithm (continuation)

\section{Conclusions.}

1. The electrical characteristics of autotransformers intended for use in the melting ice scheme with a noninductive circuit on $6-10 \mathrm{kV}$ overhead lines, which were the basis for optimization of their design parameters, have been calculated.

2. The technical and economic model of autotransformer for melting ice, which is described by nine independent variables, is developed. The method of calculation and the combined algorithm of optimization of design parameters of autotransformers for melting ice is proposed. The feature of the proposed method of calculation is the use of the criterion of the minimum value of the cost of active part and the account of the conditioned by the circuit of connecting autotransformers the technical restrictions of errors on the value and angle of secondary current.

3. Based on the obtained electrical characteristics, the design parameters of autotransformers intended for use in the melting ice scheme with a non-inductive circuit on 6$10 \mathrm{kV}$ overhead power lines are optimized. In the series of autotransformers, there are three standard sizes, which differ in maximum length of the transmission line. The current density in the primary winding of autotransformers is about $1 \mathrm{~A} / \mathrm{mm}^{2}$, whereas in the secondary one varies in the range from 1.7 to $11.3 \mathrm{~A} / \mathrm{mm}^{2}$, which is explained by different conditions of cooling of 
windings. Magnetic flux density in magnetic circuits is about $1.8 \mathrm{~T}$. The results of the design calculation are sufficient for the introduction of batch production of autotransformers for melting ice in industrial conditions.

\section{REFERENCES}

1. Farzaneh M. Atmospheric Icing of Power Networks. Berlin, Springer, 2008. $381 \mathrm{p}$.

2. Scientific and technical report on the topic "Choice of methods and development of suitable schemes for the melting of ice on the OPL of various voltage classes in the Moldovan energy system». Chisinau, STC «Techinformenergo» Publ., 2001. 132 p. (Rus).

3. Bilash I.P., Savchenko O.A. Analysis of electrical processes in the device for protecting air power lines from deposits of ice and frost. Bulletin of Kharkiv State Technical University of Agriculture, 2003, no.19, vol.1, pp. 91-98. (Ukr).

4. Biki M.A. Proektirovanie silovykh transformatorov. Raschety osnovnykh parametrov [Design of power transformers. Calculations of the main parameters]. Moscow, Znak Publ., 2013. 612 p. (Rus).

5. Del Vecchio R.M., Poulin B., Feghali P.T., Shah D.M., Ahuja R. Transformer design principles: with applications to core-form power transformers. New York, CRC Press, 2001. $599 \mathrm{p}$.

6. Tikhomirov P. M. Raschet transformatorov [Calculation of transformers]. Moscow, Energoatomizdat Publ., 1986. 582 p. (Rus).

7. Bazaraa M.S., Sherali H.D., Shetty C.M. Nonlinear programming: theory and algorithms. New Jersey, John Wiley \& Sons, 2006. $853 \mathrm{p}$

8. Timchuk S. A., Sirotenko M. A. The search algorithm for optimal reliability increasing system parameters in $10 \mathrm{kV}$ branched distribution networks. Eastern-European Journal of Enterprise Technologies, 2015, vol.6, no.8(78), pp. 4-10. (Rus). doi: 10.15587/1729-4061.2015.54626.

9. Borodakii Yu.V., Zagrebaev A.M., Kritsyna N.A., Kuliabichev Yu.P., Shumilov Yu.Yu. Nelineinoe programmirovanie $v$ sovremennykh zadachakh optimizatsii [Nonlinear programming in modern optimization problems]. Moscow, NIIaU «MIFI» Publ., 2011. 244 p. (Rus).

10. Ruban A.I., Mikhalev A.S. Global optimization with selective averaging of mixed variables: continuous and discrete with the ordered possible values. Science Bulletin of the Novosibirsk State Technical University, 2017, no.3(68), pp. 126141. (Rus). doi: 10.17212/1814-1196-2017-3-126-141.

11. Timchuk S.A. A method for constructing an algorithm for solving a nonlinear programming problem. Bulletin of Kharkiv State Technical University of Agriculture, 2004, no.23, pp. 128134. (Rus).

Received 12.02.2019

O.P. Lazurenko ${ }^{1}$, Candidate of Technical Science,

O.M. Moroz ${ }^{2}$, Doctor of Technical Science,

S.O. Tymchuk ${ }^{2}$, Doctor of Technical Science,

O.O. Miroshnyk ${ }^{2}$, Doctor of Technical Science,

O.A. Savchenko ${ }^{2}$, Candidate of Technical Science,

${ }^{1}$ National Technical University «Kharkiv Polytechnic Institute»,

2, Kyrpychova Str., Kharkiv, 61002, Ukraine,

phone+380 57 7076585, e-mail: lazurenkoap@i.ua

${ }^{2}$ Kharkiv Petro Vasylenko National Technical University of Agriculture,

44, Alchevskyh Str., Kharkiv, 61002, Ukraine,

phone+380577123432, e-mail: savoa@ukr.net

How to cite this article:

Lazurenko O.P., Moroz O.M., Tymchuk S.O., Miroshnyk O.O., Savchenko O.A. Optimization of design parameters of autotransformers in ice melting scheme with non-inductive circuit on $6-10 \mathrm{kV}$ overhead power lines. Electrical engineering \& electromechanics, 2019, no.3, pp. 59-66. doi: 10.20998/2074-272X.2019.3.10. 